\title{
Seismic Analysis of Reinforced Concrete Pier Strengthened by Carbon Fiber Reinforced Polymers
}

\author{
Sarah F. Abass ${ }^{1}$, Bassman R. Muhammad ${ }^{2}$, Qais A. Hasan ${ }^{3}$
}

\section{Authors affiliations: \\ 1) Department of Civil Engineering, University of Technology, Baghdad, Iraq 42157@student.uotechnology.edu.iq}

2) Department of Civil Engineering, University of Technology, Baghdad, Iraq 40054@uotechnology.edu.iq

3) Department of Civil Engineering, University of Technology, Baghdad, Iraq

40038@,uotechnology.edu.iq

\section{Paper History:}

Received: $17^{\text {th }}$ May 2020

Revised: $24^{\text {th }}$ June 2020
Accepted: $14^{\text {th }}$ Aug. 2020

\begin{abstract}
In this vast world after an earthquake lessons are learned; many strategies have been considered in order to achieve a proper seismic strength capacity.

The aim of this paper is studying the seismic behavior of a typical reinforced concrete bridge pier in Iraq and implementing a proper technique of strengthening in order to fix any damage that had happened.

Structure of a full scale three-dimensional finite element model was used in order to simulate a reinforced concrete pier via the computer software ABAQUS/CAE 2017 using concrete plasticity damage model (CDP).

Under the action of Halabja earthquake, which was recorded at city of Halabja in Iraq on 12 November 2017, the behavior of model was traced, analyzed and the resulted damages were managed.

The finite element analysis results indicated that the proposed configuration of carbon fiber reinforced polymers laminates substantially increases the lateral load strength and deformation capacity of the bridge pier.
\end{abstract}

Keywords: Finite Element Analysis, ABAQUS/CAE 2017, Concrete Plasticity Damage, Carbon Fiber Reinforced Polymers, Strengthening, Seismic Analysis, Halabja Earthquake.

$$
\begin{aligned}
& \text { تقوية دعامات الجسور الكونكريتية باستخدام بوليمرات الياف الكاربون } \\
& \text { سارة فاضل ، بسمان رياض، قيس عبد المجيد } \\
& \text { عالمليا وبعد حدوث عدة زلازل و ودراسه اضرارها، تم الاخذ بنظر الاعتبار عده اساليب لزيادة مقاومة }
\end{aligned}
$$

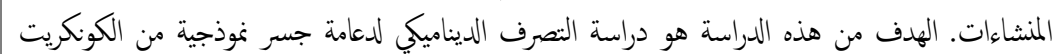

$$
\begin{aligned}
& \text { المسلح ومن ثخ استخدام طريقة مناسبة لتقوبتها ضد الزلازل. }
\end{aligned}
$$

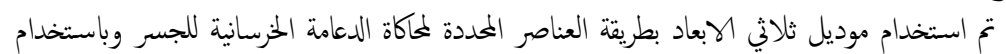

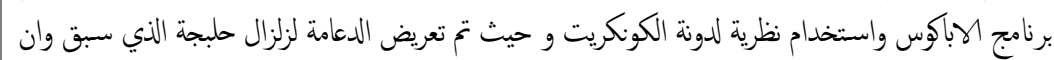

$$
\begin{aligned}
& \text { تم تسجيل تردداته بالقرب من مدينة حلبجة في العراق بتاريخ } 12 \text { نوفمبر في سنة } \\
& \text { النتائُ المستخرجة من البرنامج. }
\end{aligned}
$$

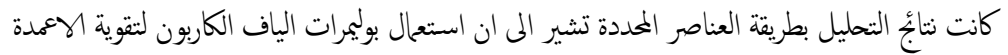

$$
\begin{aligned}
& \text { في الدعامة الخرسانية قد زاد من مقاومتها للقوى العرضية و التشوهات الجانية. }
\end{aligned}
$$

\section{Introduction:}

In the world of vital infrastructures, the goal of seismic design is to prevent life-threatening damage and to allow moderate damage in structure that can be repaired hence collapse may not be acceptable.

Though, in the past serious earthquakes, like Loma Prieta Earthquake (1989/USA), Northridge
Earthquake (1994/USA), Kobe Earthquake (1995/Japan), Bolu Earthquake (1999/Turkey) and Wenchuan Earthquake (2008/China), a great bridge suffered significant damages.

Several methods were used to strengthen bridges: restrainers, steel girder plate connections, seat extenders, column strengthening, infill wall between columns, footing and abutment strengthening, cap

NJES is an open access Journal with ISSN 2521-9154 and eISSN 2521-9162

This work is licensed under a Creative Commons Attribution-NonCommercial 4.0 International License 
beam-column joint strengthening. See figures 1,2 and 3

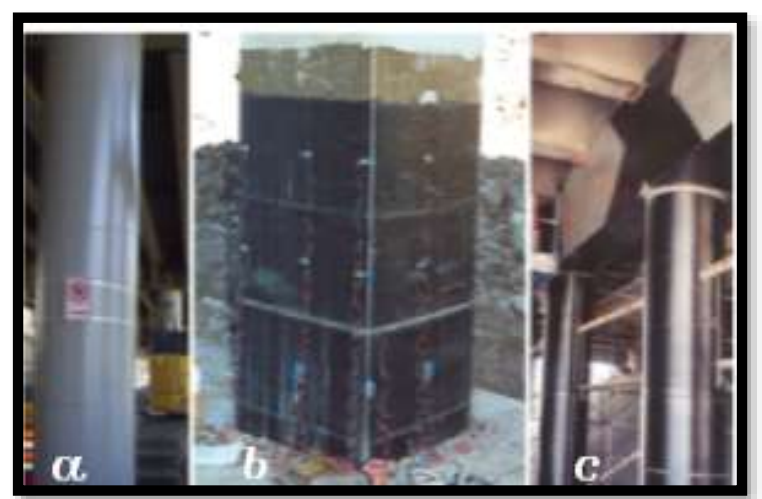

Figure (1): Column jackets: (a) steel, (b) CFRP square, (c) CFRP circular 2. Forward Kinematics Modeling

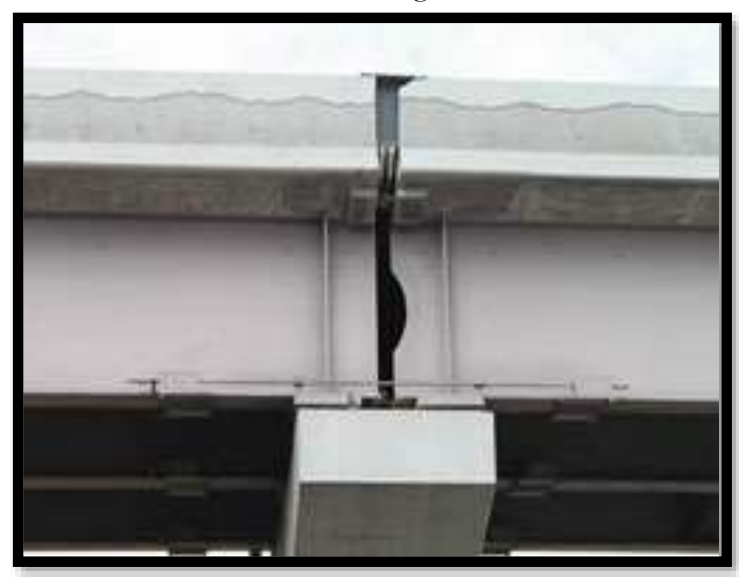

Figure (2): Steel bar restrainer

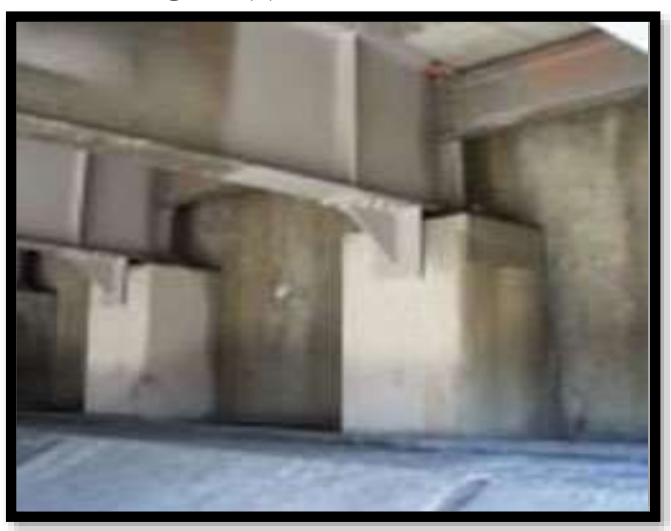

Figure (3): Bumper blocks

CFRP wraps was used as confinement in order to increase the ultimate compressive strength and the ultimate strain of the concrete, the main advantages of these wraps possess over the steel jackets are very high strength to weight ratio \& high resistivity to corrosion.

\section{Literature Review:}

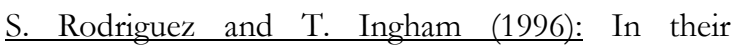
research paper described the final seismic retrofit recommended for the stiffening trusses of the Golden Gate Bridge in San Francisco, California.

The strengthening of the bridge included longitudinal hydraulic dampers to limit relative displacements, transverse dampers to isolate the south side span from the south pylon, and replacement of one half of the top lateral braces.

Lian Duan (2000): In chapter(40) of (Bridge Engineering Handbook), James Roberts and Brian Maroney explained that structural designers of bridges seismic retrofit projects must understand the system response to potential earthquake excitations, identify and design modifications to the existing system that will change the expected response to one that satisfies the seismic performance criteria.

This was accomplished by modifying the system stiffness, mass characteristics and energy absorption.

Then the chapter briefly discussed various seismic retrofit strategies used in California.

Snehansu, Dr.Nirmalendu, et al (2018): in this research paper many strategies have been considered to accomplish reliable seismic performance.

The research mainly emphasized on different isolators and dampers effect in decreasing the damage of buildings and other civil infrastructures.

It represented mechanical devices (e.g. base isolators and dampers) to improve the seismic performance.

A number of isolators such as Elastomeric Bearings, High Damping Bearings, Flat Slider Bearings, Pendulum Bearings, Ball and Roller Bearings and dampers such as Mass Dampers, Liquid Damper, Elasto-plastic Damper, Visco-Damper had been studied in details.

\section{Case Study:}

A numerical simulation was used to investigate the structural behavior of bridge pier with dimensions and properties corresponding to an exist bridge, at Qahtan square in Baghdad/Iraq, under seismic loading performed by the FE-software ABAQUS/CAE version 2017

i. Geometric Model: Qahtan Square Overpass is a simply-supported reinforced concrete bridge in Baghdad with $16 \mathrm{~m}$ width carriageway in order to have two-way traffic with two lanes each way. The pier is with four circular columns approximately $6.5 \mathrm{~m}$ in height and the deck slab is reinforced concrete with twelve girders of precast prestressed concrete and the cross-head beam with width of $1.85 \mathrm{~m}$ is used.

Figure 4, table 1 and table 2 describing concrete and reinforcement details. 


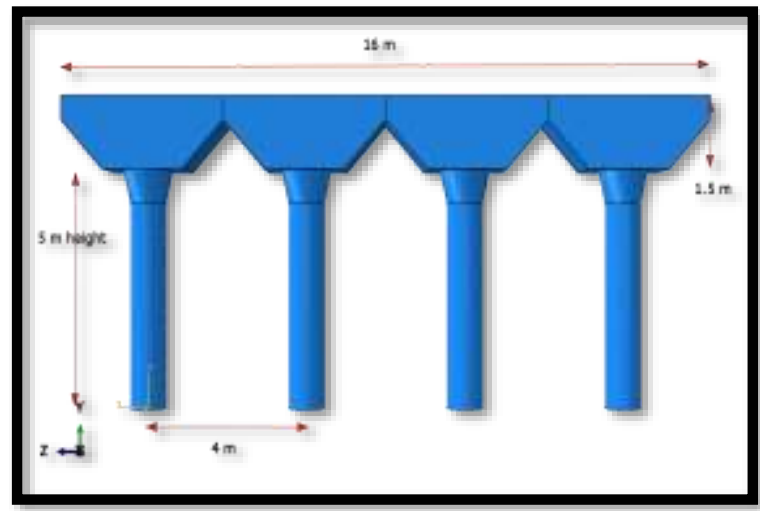

Figure (4): Bridge Pier Details

Table (1): Column details

\begin{tabular}{|c|c|c|c|c|}
\hline i & $\begin{array}{c}\text { Diameter } \\
(\mathbf{m})\end{array}$ & $\begin{array}{c}\text { Length } \\
(\mathbf{m})\end{array}$ & $\begin{array}{c}\text { Longit. } \\
\text { Reinf. }\end{array}$ & Stirrups \\
\hline Column & 0.9 & 5 & $15 \Phi 25$ & $\Phi 10 @ 200$ \\
& & & $\mathrm{~mm}$ & $\begin{array}{c}\text { mm/middle } \\
\Phi 10 @ 150 \\
\end{array}$ \\
& & & & mm/top \& bott. \\
\hline
\end{tabular}

Table (2): Crosshead beam details

\begin{tabular}{|c|c|c|c|c|c|}
\hline $\mathrm{i}$ & $\begin{array}{c}\text { Length } \\
\text { (m) }\end{array}$ & $\begin{array}{c}\text { Width } \\
\text { (m) }\end{array}$ & $\begin{array}{c}\text { Depth } \\
\text { (m) }\end{array}$ & $\begin{array}{c}\text { Longit. } \\
\text { Reinf. }\end{array}$ & Stirrups \\
\hline $\begin{array}{l}\text { Crosshead } \\
\text { beam }\end{array}$ & 16 & 1.85 & 1.5 & $\begin{array}{c}9 \Phi 25 \\
\mathrm{~mm} / \mathrm{top} \\
8 \Phi 16 \\
\mathrm{~mm} / \mathrm{middle} \\
6 \Phi 16 \\
\mathrm{~mm} / \mathrm{bott} .\end{array}$ & $\begin{array}{c}\Phi 12 @ 200 \\
\text { mm } \\
\text { Stirrups }\end{array}$ \\
\hline
\end{tabular}

Using the software Siemens NX 11.0, a threedimensional solid model of the bridge pier was generated, then imported into ABAQUS/CAE version 2017 using Initial Graphics Exchange Specification (IGES) files.

\section{ii. Materials input data:}

a. Concrete: In this study, concrete is considered to behave as nonlinear material. Plastic behavior of material was simulated by using CDP model this technique uses models which their materials are subjected to cyclic, monotonic, or dynamic loading where stiffness recovery during load reversals is permitted. Concrete used was with compressive strength (fcu) equals to $35 \mathrm{MPa}$ and all parameters were derived from the concrete compressive strength according to SIMULIA, Abaqus2016 /CAE User's Manual.

Table (3): Concrete compression and tension data

\begin{tabular}{|c|c|c|c|}
\hline $\mathbf{i}$ & Stress [MPa] & $\begin{array}{c}\text { Crushing } \\
\text { strain [+] }\end{array}$ & $\begin{array}{c}\text { Damage } \\
\mathbf{C}[+]\end{array}$ \\
\hline 1 & 24.019 & 0.0 & 0.0 \\
\hline 2 & 29.208 & 0.0004 & 0.1299 \\
\hline 3 & 31.709 & 0.0008 & 0.2429 \\
\hline 4 & 32.358 & 0.0012 & 0.3412 \\
\hline 5 & 31.768 & 0.0016 & 0.4267 \\
\hline 6 & 30.379 & 0.002 & 0.5012 \\
\hline 7 & 28.507 & 0.0024 & 0.566 \\
\hline 8 & 21.907 & 0.0036 & 0.714 \\
\hline 9 & 14.897 & 0.005 & 0.824 \\
\hline 10 & 2.953 & 0.01 & 0.9691 \\
\hline
\end{tabular}

\begin{tabular}{|c|c|c|c|}
\hline $\mathbf{i}$ & Stress [MPa] & $\begin{array}{c}\text { Cracking } \\
\text { strain [-] }\end{array}$ & $\begin{array}{c}\text { Damage } \\
\text { T [-] }\end{array}$ \\
\hline 1 & 1.78 & 0.0 & 0 \\
\hline 2 & 1.457 & 0.0001 & 0.3 \\
\hline 3 & 1.113 & 0.0003 & 0.55 \\
\hline 4 & 0.96 & 0.0004 & 0.7 \\
\hline 5 & 0.8 & 0.0005 & 0.8 \\
\hline 6 & 0.536 & 0.0008 & 0.9 \\
\hline 7 & 0.359 & 0.001 & 0.93 \\
\hline 8 & 0.161 & 0.002 & 0.95 \\
\hline 9 & 0.073 & 0.003 & 0.97 \\
\hline
\end{tabular}

CDP Parameters These parameters are needed to describe the plastic properties of concrete as the table below:

Table (4): Input data for concrete plasticity parameters

\begin{tabular}{|c|c|c|}
\hline 1 & Density & $\begin{array}{c}2.4 \times 10-9 \\
\text { tonne } / \mathrm{mm} 3\end{array}$ \\
\hline 2 & Young's modulus E & $25399 \mathrm{MPa}$ \\
\hline 3 & Poisson's ratio $\nu$ & 0.2 \\
\hline 4 & Dilation angle $\Phi$ & $36^{\circ}$ (default) \\
\hline 5 & $\begin{array}{c}\text { Flow potential } \\
\text { eccentricity } \epsilon\end{array}$ & 0.1 (default) \\
\hline 6 & $\begin{array}{c}\text { Biaxial/uniaxial } \\
\text { compression plastic } \\
\text { strain ratio fb0/fC0 }\end{array}$ & 1.16 (default) \\
\hline 7 & $\begin{array}{c}\text { Invariant stress ratio } \\
\text { KC }\end{array}$ & 0.667 (default) \\
\hline 8 & Viscosity V & 0.000001 \\
\hline
\end{tabular}

b. Reinforcement: For the bridge pier, a perfectly plastic material model is used to define steel plasticity by using ASTM deformed reinforcing steel bars grade 60 for $\mathrm{fy}=414 \mathrm{Mpa}$. table 4 describes steel bars data.

Table (5): Steel plastic data

\begin{tabular}{|c|c|c|}
\hline $\mathbf{i}$ & Stress [MPa] & Plastic strain \\
\hline 1 & 413.69 & 0 \\
\hline 2 & 414.89 & 0.008 \\
\hline 3 & 482.63 & 0.020 \\
\hline 4 & 551.58 & 0.040 \\
\hline 5 & 592.95 & 0.060 \\
\hline 6 & 620.53 & 0.080 \\
\hline 7 & 592.95 & 0.100 \\
\hline 8 & 551.58 & 0.130 \\
\hline
\end{tabular}

iii. Boundary conditions: A totally fixed bottom of pile cap was used, as well as an acceleration mechanical boundary condition was used at side of the pile cap representing the earthquake excitation.

iv. Bridge loading: The loads involved in bridge pier structure were:

$\checkmark \quad$ Supper structure loads (i.e. dead load + imposed dead load) applied as pressure load on crosshead beam top.

$\checkmark$ Traffic live loading as claimed by Iraqi specifications for loading of bridges applied as pressure load on crosshead beam top.

$\checkmark \quad$ Pier gravity load 
$\checkmark$ Doubled(for exaggerated load case) Halabja earthquake loading applied in biaxial direction (i.e. in $\mathrm{X}$ and $\mathrm{Z}$ direction together).

See figures 5, 6, 7 .

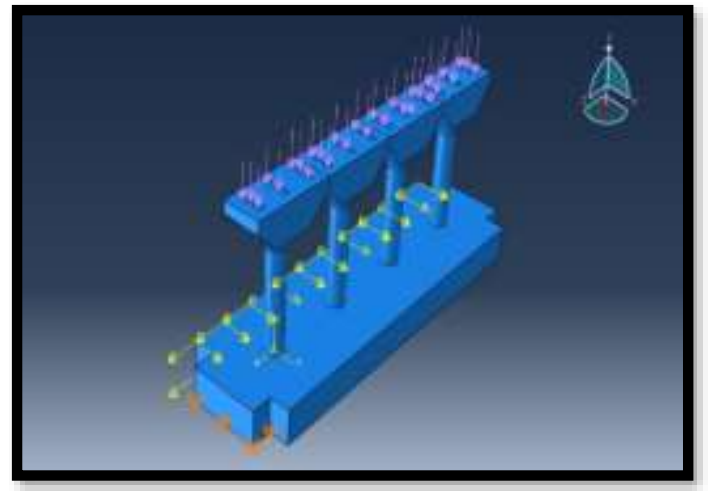

Figure (5): Loading and Boundary Conditions

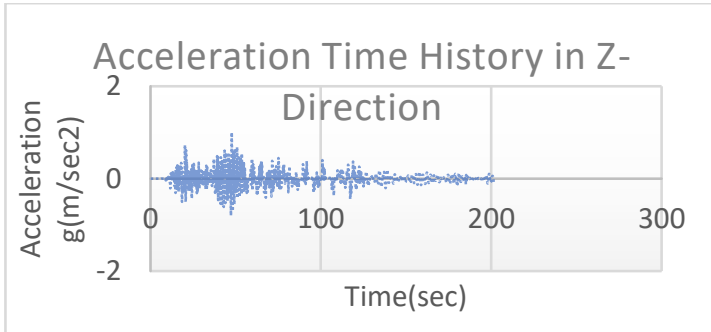

Figure (6): Halabja Earthquake Intensity (xdirection)

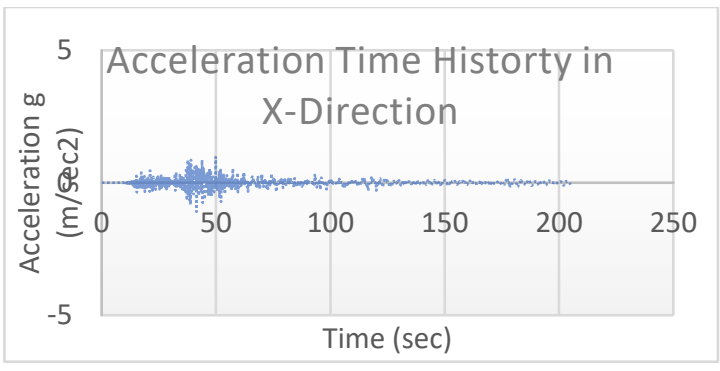

Figure (7): Halabja Earthquake Intensity (zdirection).

Figures 6, 7 shows the data of earthquake used in the analysis which is an acceleration record.

The method of dynamic analysis used to analyze the structure under the earthquake was Time History Method

v. Meshing: For concrete a quadratic brick element was selected to provide higher accuracy for elements with strong distortions. That element type captures stress concentrating better furthermore effective in bending and shear problems. Truss elements were selected in order that the reinforcing steel bars didn't supply high bending stiffness. Table 6 summarized a statistic data of model elementsError! Reference source not found. 8 and Figure 9 illustrate the finite element meshes that were adopted for concrete and reinforcement bars.

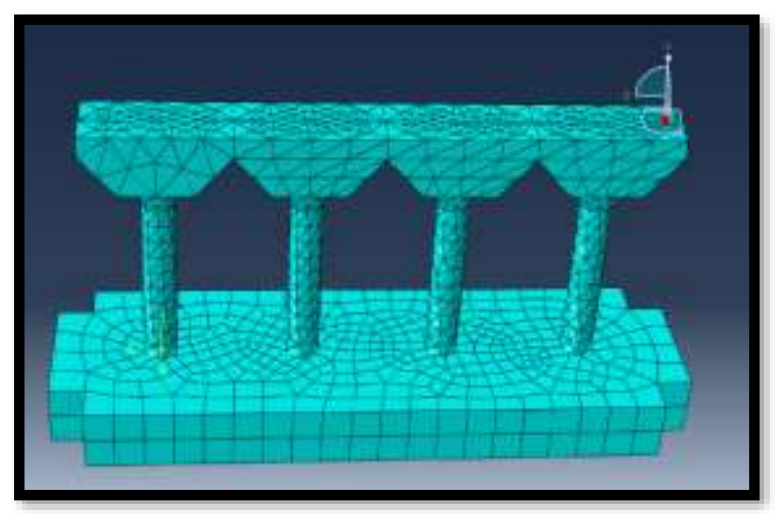

Figure (8): Concrete Mesh

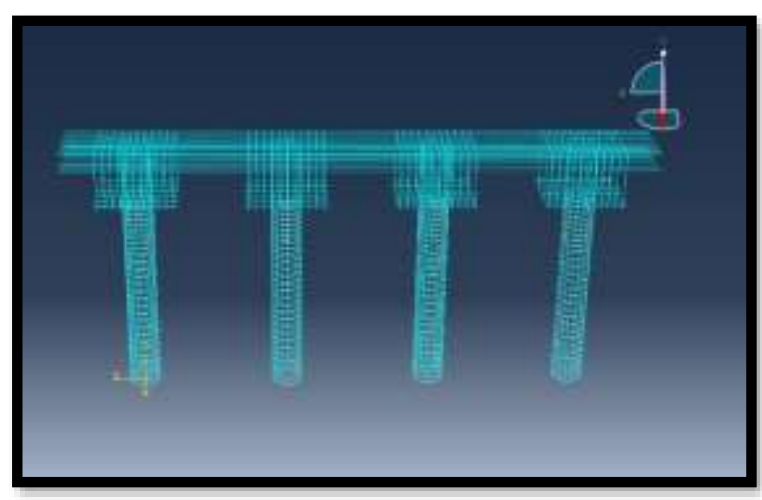

Figure (9): Reinforcement Mesh

Table (6): Statistic of elements used in model

\begin{tabular}{|c|c|c|c|c|}
\hline Pier part & $\begin{array}{c}\text { Element } \\
\text { type }\end{array}$ & $\begin{array}{c}\text { Element } \\
\text { shape }\end{array}$ & $\begin{array}{c}\text { Geometric } \\
\text { order }\end{array}$ & Element \\
\hline $\begin{array}{c}\text { Concrete } \\
\text { of pier }\end{array}$ & C3D10 & $\begin{array}{c}\text { tetrahedr } \\
\text { al }\end{array}$ & quadratic & 4489 \\
\hline $\begin{array}{c}\text { Reinforcin } \\
\text { g bars }\end{array}$ & T3D2 & line & linear & 3339 \\
\hline $\begin{array}{c}\text { Concrete } \\
\text { of pile cap }\end{array}$ & C3D8 & $\begin{array}{c}\text { hexahedr } \\
\text { al }\end{array}$ & linear & 692 \\
\hline
\end{tabular}

\section{Case Study Results:}

Halabja earthquake was chosen for the following reasons:

* It is up to date recorded Iraqi earthquake.

* To check the typical Iraqi bridge substructures to real earthquake happened in Iraq.

Doubling Halabja excitation in biaxial direction and assuming no compression stiffness recovery would expose the pier to a severe stress in both compression and tension at concrete and additional von mises stresses at reinforcement bars.

The compression damage ratio recorded as $151.4 \%$ of concrete compression crushing parameter, which passed the limits of the pier's concrete plastic damage, at lower parts of the four columns and some spots at the cross head beam and was reached to the plastic hinge stage,

The maximum mises stresses in steel bars in the end of earthquake excitation was $518.9 \mathrm{Mpa}$, at the longitudinal main bars and hoops of the columns 
exceeding the yield limits, this would be illustrated as in the figures 10,11

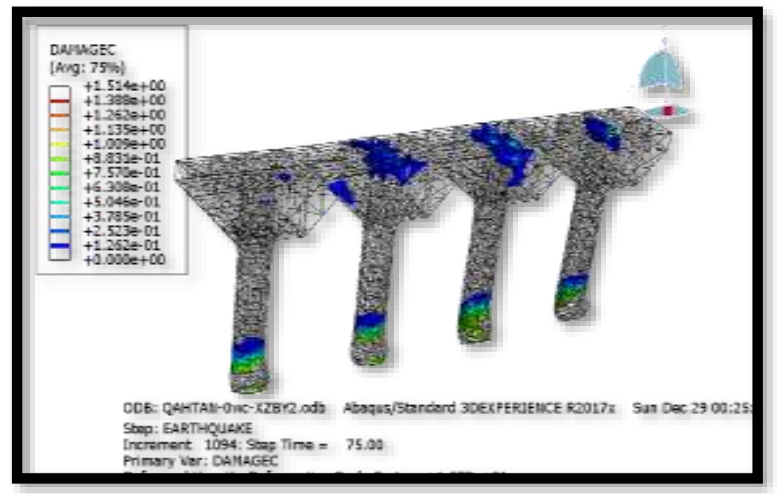

Figure (10): Compression damage patterns for pier in Concrete

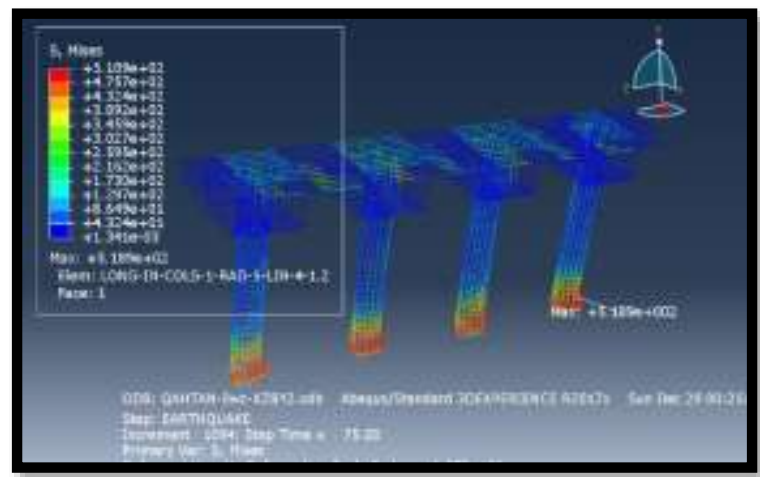

Figure (11): Stresses pattern in bars

\section{CFRP Strengthening:}

During recent decades CFRP wraps used to increase the ultimate compressive strength and the ultimate strain of the concrete, the main advantages of these wraps possess over the steel jackets are very high strength to weight ratio \& high resistivity to corrosion By strengthening columns before exposing the pier to earthquake excitation at the previous case study, a common finite element technique was implemented via $A B A Q U S$ software.

\section{i. $\quad$ CFRP material properties:}

Table7 describes CFRP's material properties

Table (7): Mechanical properties of CFRP laminates

\begin{tabular}{|c|c|c|c|}
\hline 1 & Nominal thickness $(\mathrm{mm})$ & $\mathrm{t}$ & 0.13 \\
\hline 2 & Elastic modulus $(\mathrm{MPa})$ & $\mathrm{E} 1$ & 230000 \\
& & $\mathrm{E} 2$ & 17900 \\
\hline 3 & Tensile strength $(\mathrm{MPa})$ & $\mathrm{ffu}$ & 3500 \\
& & & \\
\hline 4 & Shear modulus $(\mathrm{MPa})$ & $\mathrm{G} 12$ & 11790 \\
& & $\mathrm{G} 13$ & 11790 \\
& & $\mathrm{G} 23$ & 6880 \\
\hline 5 & Poisson's ratio $(\mathrm{V})$ & $\mathrm{v} 12$ & 0.22 \\
& & $\mathrm{v} 13$ & 0.22 \\
& & $\mathrm{v} 23$ & 0.3 \\
\hline 6 & Ultimate strain $(\%)$ & $\varepsilon f u$ & 1.5 \\
\hline 7 & Density(tonne $\left./ \mathrm{mm}^{3}\right)$ & & $1.6 \times 10^{-9}$ \\
\hline
\end{tabular}

ii. CFRP finite element type and mesh: The assumed (2 meter) FRP sheet was modeled utilizing a (640) of S4R elements (a 4-node doubly curved thin or thick shell, finite membrane strains, in one direction orientation (i.e X-direction), see figures below:

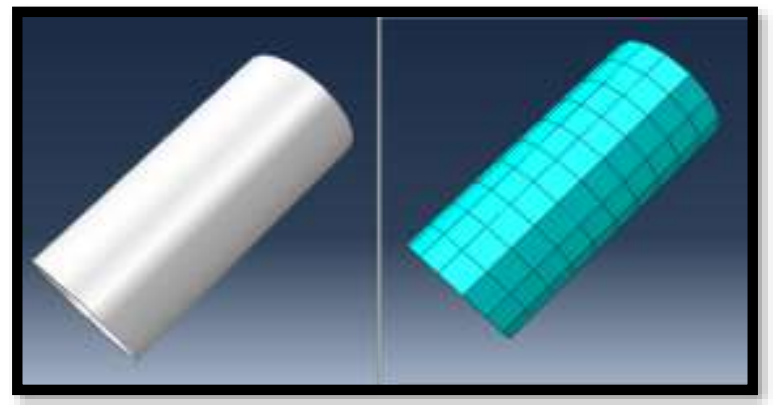

Figure (12): Finite element model of CFRB jacket.

The CFRP elements are connected to the concrete directly using interaction with concrete elements by surface to surface contact property.

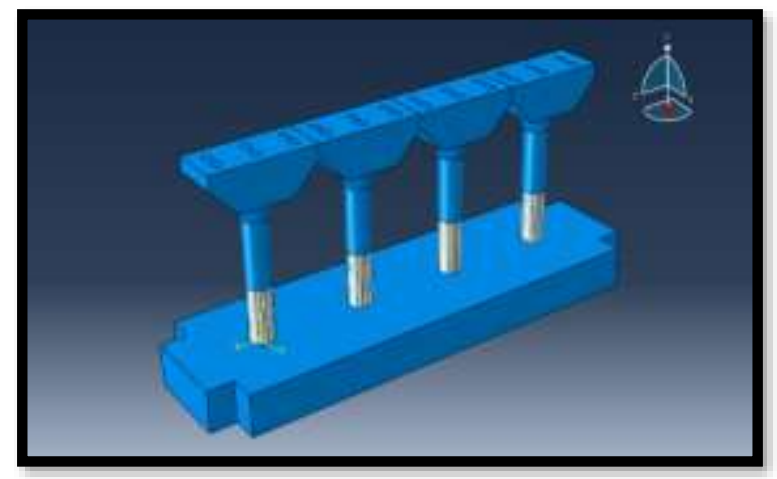

Figure (13): The strengthened finite element model

iii. Strengthening Results:

After strengthening process, the compression damage ratio recorded was not different from the previous failure records nevertheless, the maximum record of crushing parameter is less propagated in the structure after strengthening, see figure 14 .

The tension cracking was less specifically in the inferior parts of columns but the cracking parameters were identical, see figure 15 .

The maximum mises stresses in steel bars in the end of earthquake excitation was reduced from 518.9 $\mathrm{Mpa}$ to $414 \mathrm{Mpa}$ with obvious improvement in deformed shape, see figure 16.

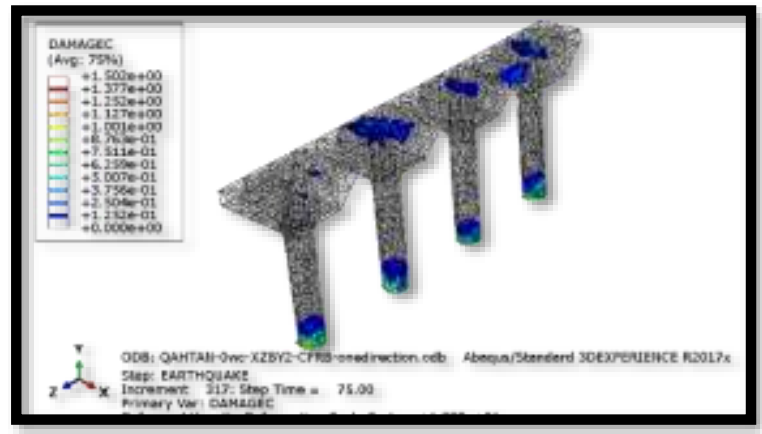

Figure (14): Compression damage patterns for pier (strengthened columns) 


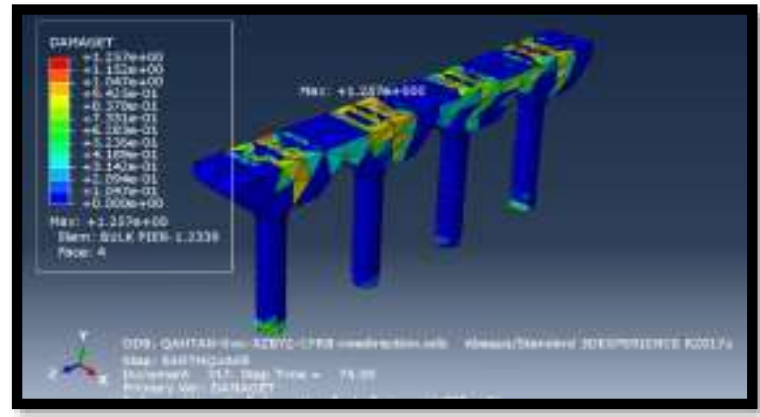

Figure (15): Tension damage patterns for pier (strengthened columns)

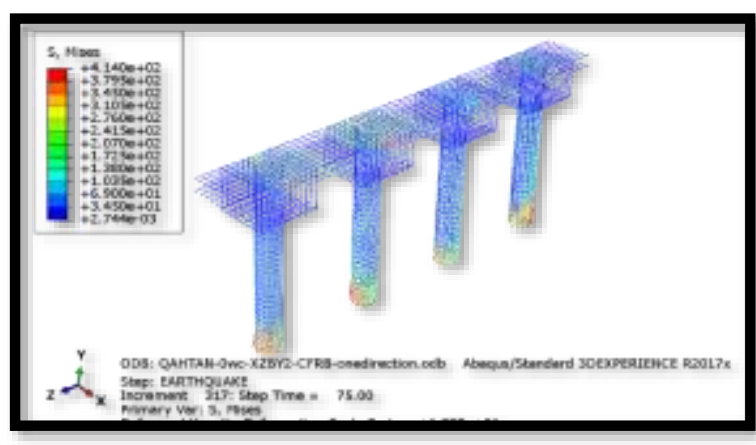

Figure (16): Stresses pattern in bars (strengthened columns)

\section{Conclusions:}

1. Using Concrete Damaged Plasticity analysis method had enhanced the capacity of pier to resist earthquakes due to the effect of compression and tension plastic damage parameter.

2. The maximum stresses in pier's concrete and reinforcement were occurred at the inferior regions of columns and some little spots in the cross-head beam in model.

3. The proposed configuration of CFRP laminates increases lateral load strength and deformation capacity at the CFRB-confined portions.

4. The FEM analysis results indicated: less compression crushing, less tension cracking, less von mises stresses and deformations reinforcement bars and hoops.

\section{References:}

[1] A. /. U. M. SIMULIA, AVAILABLE AT http://130.149.89.49:2080/v2016/index.html.

[2] Mohamed Hegazy, Mohamed Husain and Ahmed Eisa , "Strengthening of reinforced concrete shear walls with openings using carbon fiber-reinforced polymers," International Journal of Advanced Structural Engineering, p. pp 129-150, 2019.

[3] C. Pantelides, "Strengthening techniques: Bridges," Encyclopedia of Earthquake Engineering journal, 2014.

[4] Abbas Al-Taie and Bushra Albusoda, "Earthquake hazard on Iraqi soil: Halabjah earthquake as a case study," Geodesy and Geodynamics journal, pp. pp 196-204, 2019.

[5] Saif Shawkat, Ammar Abdul Rahman, "Influence of adding infill walls on the behavior of R.C. frames during earthquakes," International Journal of Applied Engineering Research, pp. pp. 10397-10414, 2017.

[6] AASHTO, AASHTO Guide Specifications for LRFD Seismic Bridge Design, Washington, DC: American Association of State Highway and Transportation Officials, 2017.

[7] S. Rodriguez and T. Ingham, "Seismic protective systems for the stiffening truss of the golden gate bridge," in Eleventh World Conference on Earthquake Engineering, 1996.

[8] Lian Duan and Wai-Fah Chen, Earthquake engineering handbook, CRC PRESS, 2000.

[9] Snehansu Nath, Dr. Nirmalendu Debnath and Prof. Satyabrata Choudhury, "Methods for improving the seismic performance of structures," in IOP Conference Series: Materials Science and Engineering, 2018.

[10] H. A. HASAN, Finite Elemene Analysis of Bridge Substructure Subjected to Earthquake, A master Thesis / Al-Nahrain University, 2012. 